\title{
PEMBUATAN APLIKASI PRAKTIS DESAIN BLOK ACAK LENGKAP MENGGUNAKAN BAHASA PEMROGRAMAN LAZARUS
}

\author{
Budhi Handoko \\ Departemen Statistika, Universitas Padjadjaran \\ budhi.handoko@unpad.ac.id \\ Yeny Krista Franty \\ Departemen Statistika, Universitas Padjadjaran \\ Gumgum Darmawan \\ Departemen Statistika, Universitas Padjadjaran
}

\begin{abstract}
Completely Randomized Block Design is one type of design experiments in Statistics which is used to conduct experiment involving treatments and blocks. Blocking is used to make experimental unit become homogen in each blok. Analysis to the reults of the experiment using the design usually perform using licensed software such as SPSS or Minitab. In order to use those softwares, we have to buy the license. In addition, if use them, we have to arrange the data into column form which require knowledge about orthogonality principle. This research will develop an application to analyze the experimental data easily, because the input in the form of table that suitable with experimental data format. In this research we used Lazarus Visual Programming which is one of open source software. The result of this research is a practical application that can be used to analyze experimental result produced using completely randomized block design which is bery easy to use. Experimental data from table of experimental result can be directly copied into the cells of the program thus data entry can be fastened. This program is an executable file (*.exe) so it is not necessary to be installed and the size of file is small enough which is 19 megabyte.
\end{abstract}

Keywords: Statistical Design of Experiment, Completely Randomized Block Design, Lazarus Programming, Visual Programming.

\begin{abstract}
ABSTRAK. Desain Blok Acak Lengkap merupakan salah satu desain dalam Statistika yang digunakan untuk melakukan suatu eksperimen yang melibatkan perlakuan dan pemblokan. Pemblokan dilakukan untuk membuat unit eksperimen menjadi homogen dalam setiap blok. Analisis terhadap data hasil eksperimen menggunakan desain tersebut biasanya dilakukan dengan menggunakan software yang berlisensi seperti SPSS, atau Minitab. Untuk dapat menggunakan software tersebut harus membeli lisensinya. Apabila menggunakan software tersebut, pengguna harus menyusun data dalam bentuk data per kolom yang harus mengetahui prinsip orthogonalitas. Penelitian ini bertujuan membuat suatu aplikasi untuk menganalisis secara lebih mudah, karena input data berupa tabel yang sesuai dengan format data hasil eksperimen. Bahasa pemrograman yang digunakan untuk membuat aplikasi tersebut adalah bahasa pemrograman visual Lazarus yang merupakan salah satu software open source. Hasil dari penelitian ini adalah aplikasi praktis yang dapat digunakan untuk menganalisis hasil eksperimen yang menggunakan desain blok acak lengkap yang sangat mudah untuk digunakan. Data eksperimen pada
\end{abstract}


tabel hasil eksperimen bisa langsung di-copy-kan pada sel-sel pada program sehingga mempercepat entry data. Program ini berupa executable file (*.exe) sehingga tidak perlu instalasi dan ukuran dari filenya cukup kecil hanya sekitar 19 megabyte.

Kata Kunci: Statistika Desain Eksperimen, Desain Blok Lengkap Acak, Bahasa Pemrograman Lazarus, Pemrograman Visual.

\section{PENDAHULUAN}

Desain Blok Acak Lengkap merupakan sebuah desain yang digunakan untuk melakukan eksperimen dengan unit eksperimen yang tidak homogen sehingga memerlukan pemblokan. Pemblokan dilakukan untuk membuat agar unit eksperimen dalam satu blok menjadi homogen. Dengan adanya pemblokan untuk mengendalikan homogenitas unit eksperimen ini memberikan konsekuensi adanya penambahan sumber variasi dalam Tabel Analisis Varians (Anava) yaitu sumber variasi Blok.

Penambahan sumber variasi Blok ini juga menjadi salah satu pekerjaan bagi analis data hasil eksperimen untuk bisa menyelesaikan analisis Desain Blok Acak Lengkap (DBAL) secara sempurna. Peneliti yang berasal dari luar Bidang Statistika seringkali mengalami kesulitan dalam proses analisis data hasil eksperimen tersebut disebabkan perhitungan yang cukup banyak dan memerlukan ketelitian yang tinggi agar tidak mengalami kekeliruan. Selain itu, teknik analisis yang berbeda-beda untuk setiap desain juga menjadi salah satu kesulitan tersendiri bagi peneliti.

Dalam usaha untuk dapat menyelesaikan analisis data, biasanya peneliti berkonsultasi dengan para statistisi atau konsultan statistik. Sebagian peneliti yang memiliki pengetahuan mengenai software statistika seperti SPSS akan menggunakan software tersebut untuk membantu menyelesaikan analisis data.Analisis data DBAL menggunakan SPSS misalnya telah dilakukan oleh Pitri, (2014) dan juga oleh Rahmiyana (2014). Analisis DBAL juga dapat menggunakan software Minitab yang telah dibahas dalam Mathews (2005) dan analisisnya seperti yang telah dilakukan oleh Andini (2015) dan Lauterboom (2010) Namun, penggunaan software SPSS atau Minitab sendiri dalam analisis data desain eksperimen juga akan menghadapi masalah, karena inputan dalam spreadsheet 
SPSS/Minitab yang diperlukan tidak sama dengan format pencatatan yang dilakukan oleh peneliti. Hal ini disebabkan entry data dilakukan dalam format per kolom atau disebut data unstack. Untuk dapat meng-entry data dalam bentuk yang unstack tersebut, peneliti harus mengetahui konsep orthogonalitas desain, yaitu kombinasi dari setiap perlakuan dan respon tidak boleh ada yang berulang atau unik setiap barisnya. Apabila hal tersebut dilanggar akan menimbulkan software tidak dapat menjalankan analisisnya.

Berdasarkan permasalahan tersebut, penelitian ini bertujuan untuk membuat suatu aplikasi praktis yang dapat dimanfaatkan oleh pengguna dari berbagai kalangan yang seringkali melakukan eksperimen menggunakan Desain Blok Acak Lengkap agar dapat melakukan analisis dengan mudah dan cepat.

Artikel ini terdiri atas pendahuluan yang merupakan landasan yang menjadi dasar pemikiran penelitian. Selanjutnya adalah metode penelitian yang berisi mengenai bagaimana program dibuat beserta konsep dasar mengenai desain blok acak lengkap dan tools dalam Bahasa Pemrograman Lazarus. Bagian tiga adalah hasil dan pembahasan berisi urain hasil aplikasi program yang terbentuk, dan bagian terakhir adalah kesimpulan mengenai penelitian ini dan saran untuk penelitian selanjutnya.

Hasil dari penelitian ini adalah aplikasi praktis yang dapat digunakan untuk menganalisis hasil eksperimen yang menggunakan desain blok acak lengkap yang sangat mudah untuk digunakan. Data eksperimen pada tabel hasil eksperimen bisa langsung di-copy-kan pada sel-sel pada program sehingga mempercepat entry data. Program ini berupa executable file (*.exe) sehingga tidak perlu instalasi dan ukuran dari filenya cukup kecil hanya sekitar 19 megabyte.

\section{METODE PENELITIAN}

Berikut ini akan dijelaskan mengenai Konsep Desain Blok Acak Lengkap (DBAL), Tabel Analisis Varians dalam DBAL, Bahasa Pemrograman Lazarus, pembentukan desain program, dan langkah penyusunan program. 


\subsection{Konsep Dasar Desain Blok Acak Lengkap}

Desain Blok Acak Lengkap (DBAL) merupakan salah satu bentuk desain eksperimen yang digunakan dalam eksperimen faktor tunggal dengan unit eksperimen yang tidak homogen. Desain ini menggunakan pemblokan untuk membuat sedemikian rupa sehingga unit eksperimen dalam blok menjadi homogen sedangkan unit eksperimen antar blok menjadi heterogen (Sudjana, 2002).

Model linier dari DBAL adalah seperti pada persamaan (1) berikut ini:

$$
\begin{aligned}
& y_{i j}=\mu+\beta_{i}+\tau_{j}+\varepsilon_{i j} \\
& \mathrm{i}=1,2, \ldots, \mathrm{b} \text { (banyak blok) } \\
& \mathrm{j}=1,2, \ldots, \mathrm{p} \text { (banyak perlakuan) }
\end{aligned}
$$

dengan:

$y_{i j}=$ variabel respon eksperimen pada perlakukan ke-i, replikasi ke-j

$\mu=$ rata-rata umum atau rata-rata sebenarnya

$\beta_{i}=$ efek blok ke-i

$\tau_{j}=$ efek perlakuan ke-j

$\varepsilon_{i j}=$ kekeliruan yang merupakan efek acak dari unit eksperimen ke-j

karena dikenai perlakuan ke-i.

Dalam desain ini, tujuan dari analisis adalah untuk melakukan pengujian hipotesis terhadap rata-rata perlakuan dan untuk menaksir nilai rata-ratanya. Dalam rangka pengujian hipotesis, error dari model diasumsikan merupakan variabel acak yang berdistribusi normal dan independen dengan rata-rata nol dan varians $\sigma^{2}$. Dan varians diasumsikan konstan untuk semua taraf dari faktor tersebut. (Montgomery, 2012).

Data hasil eksperimen menggunakan DBAL seringkali disusun kedalam sebuah tabel yang terdiri atas baris dan kolom. Kolom menyatakan perlakukan dan baris menyatakan banyaknya blok yang dibentuk. Perlakuan dalam eksperimen dimisalkan sebanyak $p$ buah dan banyaknya blok adalah $b$. Nilai yang 
ada dalam sel-sel tersebut merupakan nilai respon hasil eksperimen. Selengkapnya bisa dilihat pada Tabel 1 berikut ini.

Tabel 1. Struktur Data Eksperimen DBAL

\begin{tabular}{|c|c|c|c|c|}
\hline \multirow{2}{*}{ Blok } & \multicolumn{4}{|c|}{ Perlakuan } \\
\cline { 2 - 5 } & $\mathbf{1}$ & $\mathbf{2}$ & $\cdots$ & $\boldsymbol{p}$ \\
\hline 1 & $\mathrm{y}_{11}$ & $\mathrm{y}_{21}$ & $\cdots$ & $\mathrm{y}_{\mathrm{p} 1}$ \\
\hline 2 & $\mathrm{y}_{12}$ & $\mathrm{y}_{22}$ & $\cdots$ & $\mathrm{y}_{\mathrm{p} 2}$ \\
\hline$\vdots$ & $\vdots$ & $\vdots$ & $\ddots$ & $\vdots$ \\
\hline$b$ & $\mathrm{y}_{1 \mathrm{~b}}$ & $\mathrm{y}_{2 \mathrm{~b}}$ & $\cdots$ & $\mathrm{y}_{\mathrm{pb}}$ \\
\hline
\end{tabular}

\subsection{Tabel Analisis Varians Dalam DAS}

Berdasarkan model pada persamaan (1) maka DBAL memiliki empat buah sumber variasi, yaitu rata-rata, efek blok, efek perlakuan, dan kekeliruan eksperimen. Keempat sumber variasi tersebut akan dimasukkan kedalam Tabel Analisis Varians (Anava) untuk menganalisis hasil eksperimen yang diperoleh menggunakan DBAL.

Adapun Tabel Anava untuk DBAL disajikan seperti pada Tabel 2 berikut ini.

Tabel 2. Tabel Anava DBAL

\begin{tabular}{|c|c|c|c|c|}
\hline Sumber Variasi & $\begin{array}{c}\text { Derajat } \\
\text { bebas }\end{array}$ & $\begin{array}{c}\text { Jumlah } \\
\text { Kuadrat (JK) }\end{array}$ & $\begin{array}{c}\text { Rata-rata Jumlah } \\
\text { Kuadrat (RJK) }\end{array}$ & F hitung \\
\hline Rata-rata & 1 & $\mathrm{JK}(\mathrm{R})$ & $\operatorname{RJK}(\mathrm{R})$ & \\
\hline Blok & $\mathrm{b}-1$ & $\mathrm{JK}(\mathrm{B})$ & $\operatorname{RJK}(\mathrm{B})$ & \\
\hline Perlakuan & $\mathrm{p}-1$ & $\mathrm{JK}(\mathrm{P})$ & $\operatorname{RJK}(\mathrm{P})$ & $\operatorname{RJK}(P)$ \\
\hline $\begin{array}{c}\text { Kekeliruan } \\
\text { Eksperimen }\end{array}$ & $(\mathrm{b}-1)(\mathrm{p}-1)$ & $\mathrm{JK}(\mathrm{E})$ & $\mathrm{RJK}(\mathrm{E})$ & \\
\hline Jumlah & $\mathrm{Bp}$ & $\mathrm{JK}(\mathrm{T})$ & & \\
\hline
\end{tabular}

Perhitungan jumlah kuadrat (JK) dilakukan menggunakan perumusan seperti berikut ini: 


$$
\begin{aligned}
& J K(T)=\sum_{i=1}^{p} \sum_{j=1}^{n} Y_{i j}^{2} \\
& J K(R)=\frac{Y_{. .}^{2}}{p n} \\
& J K(B)=\sum_{i=1}^{p}\left(y_{i \bullet}^{2} / p\right)-J K(R) \\
& J K(P)=\sum_{j=1}^{b}\left(y_{\bullet j}^{2} / b\right)-J K(R) \\
& J K(E)=J K(T)-J K(R)-J K(B)-J K(P)
\end{aligned}
$$

Perumusan hipotesis dalam pengujian Anava adalah menguji efek dari perlakuan apakah signifikan atau tidak. Adapun perumusan hipotesisnya adalah sebagai berikut:

$$
\begin{aligned}
& H_{0}: \tau_{j}=0 \\
& H_{1}: \tau_{j} \neq 0
\end{aligned}
$$

Hipotesis nol melakukan pengujian bahwa efek perlakuan tidak signifikan terhadap respon, sedangkan hipotesis satu menyatakan bahwa efek perlakuan signifikan pada taraf nyata $\alpha$.

\subsection{Bahasa Pemrograman Lazarus}

Lazarus merupakan perangkat pengembangan aplikasi berbasis pascal dilingkungan Linux. Dalam perkembangannya Lazarus juga mendukung berbagai platform lain seperti Windows, Mac OS dan Solaris (Tantular, 2013). Lazarus merupakan sebuah software open source dengan free lisensi sehingga dapat dapat diperoleh dengan cara mengunduhnya secara gratis Lazarus IDE berikut Free Pascal Compiler-nya di situs http://www.lazarus-ide.org/. Lazarus adalah sebuah perangkat lunak (bahasa pemrograman) untuk membuat program/aplikasi komputer berbasis windows. Lazarus merupakan bahasa pemograman berbasis objek, artinya semua komponen yang ada merupakan objek-objek. Ciri sebuah 
objek adalah memiliki nama, properti dan method/procedure. Lazarus disebut juga visual programming artinya komponen-komponen yang ada tidak hanya berupa teks (yang sebenarnya program kecil) tetapi muncul berupa gambar-gambar.

Beberapa komponen dalam dalam pemrograman Lazarus yang digunakan untuk pembuatan program aplikasi yaitu:

1. TForm

Form (atau formulir) ini merupakan tampilan visual yang digunakan untuk melakukan input dan ouput dengan format sesuai dengan keinginan dari pengguna. Form merupakan salah satu ciri khas dalam pemrograman lazarus yang merupakan pemrograman visual yang tampilannya berupa window/jendela. Tampilan dasar form pada Lazarus seperti pada Gambar 1 berikut ini:

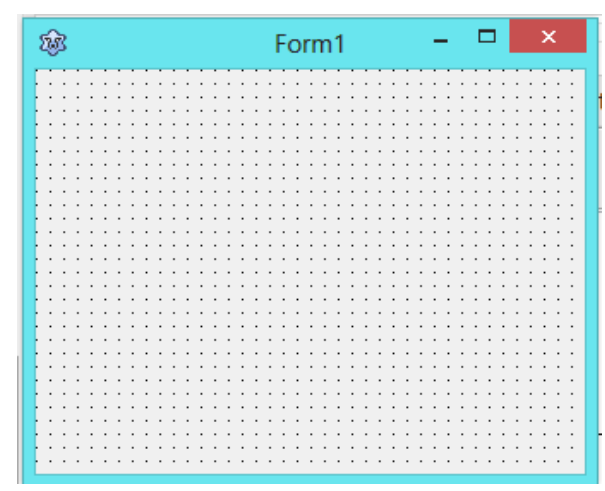

Gambar 1. Tampilan Form dalam Lazarus

\section{TButton}

Button (atau tombol) digunakan untuk melakukan aksi eksekusi program dan nantinya akan tampil output dari hasil analisis. Pembuatan sintaks program juga akan dilakukan melalui tombol ini dengan cara meng-klik dua kali kemudian akan masuk ke Source Editor. Bentuk button seperti pada gambar berikut ini:

\section{Button1}

Gambar 2. Button pada Lazarus 
3. TLabel

Label digunakan untuk memeberikan keterangan terhadap input atau output yang dilakukan dan dihasilkan pada formulir.

4. TEdit

Edit seringkali digunakan untuk menyimpan nilai input pada formulir atau bisa juga menampilkan nilai output program pada formulir. Tampilan dari edit pada formulir adalah seperti pada Gambar 3.

\section{Edit1}

Gambar 3. Edit pada Lazarus

5. TStringGrid

StringGrid (atau kisi tali) berbentuk kotak-kotak atau sel seperti matriks kosong yang dapat menampung nilai-nilai dalam jumlah yang cukup banyak. Stringgrid ini bisa digunakan untuk melakukan input dan output dalam Lazarus. Tampilan kisi tali seperti pada Gambar 4.

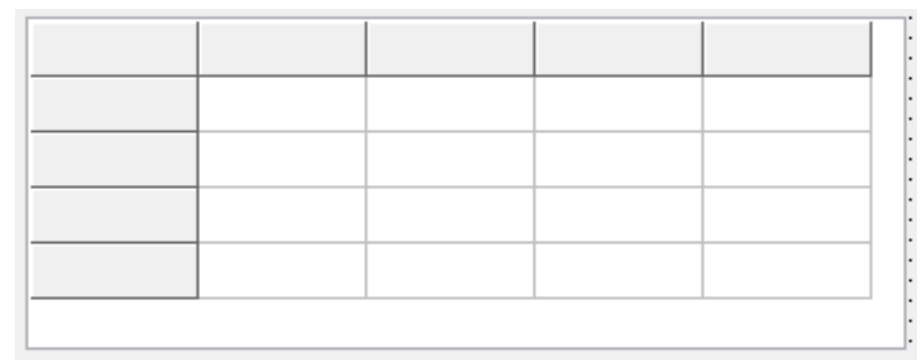

Gambar 4. StringgGrid dalam Lazarus

\subsection{Pembentukan Desain Program}

Desain Program Lazarus untuk menyelesaikan analisis hasil eksperimen yang diperoleh menggunakan DAS dibuat supaya dapat mudah digunakan oleh pengguna (user friendly). Pengguna dari berbagai kalangan diharapkan dapat menggunakan program ini dengan mudah tanpa harus memahami terlebih dahulu bagaimana perhitungan dalam menentukan Tabel Anava. 
Desain formulir Lazarus dirancang untuk menerima inputan berupa banyaknya perlakuan, banyaknya percobaan, dan data hasil eksperimen. Inputan berupa banyak perlakuan dan banyaknya percobaan dilakukan dengan menggunakan menu Edit. Sedangkan untuk data hasil eksperimen menggunakan menu StringGrid. Untuk dapat menampung nilai-nilai pada StringGrid dengan dimensi yang berubah-ubah sesuai dengan banyaknya perlakuan dan percobaan digunakan array dinamis. Suatu array x merupakan suatu array dinamis dengan nilai inputan berupa bilangan real dideklarasikan sebagai berikut:

$$
x \text { : array of array of real }
$$

\subsection{Langkah-langkah analisis Dalam Program}

Langkah-langkah dalam Program terdiri atas Input, Proses, dan Output sebagai berikut:

a. Input

1. Input banyaknya perlakuan $(p)$

2. Input banyaknya blok $(b)$

3. Input Data hasil Eksperimen $(b \times p)$

b. Proses

1. Menghitung Jumlah Kuadrat Total, Jumlah Kuadrat Rata-rata, Jumlah Kuadrat Blok, Jumlah Kuadrat Perlakuan. Jumlah Kuadrat Kekeliruan Eksperimen

2. Menghitung derajat bebas Rata-rata, Blok, Perlakuan, Kekeliruan Eksperimen, dan Total

3. Menghitung Jumlah Kuadrat Total, Jumlah Kuadrat Rata-rata, Jumlah Kuadrat Blok, Jumlah Kuadrat Perlakuan, Jumlah Kuadrat Kekeliruan Eksperimen

4. Menghitung Nilai Statistik F

c. Output

Menampilkan hasil perhitungan yang dilakukan pada bagian Proses kedalam Tabel Analisis Varians. 


\section{HASIL DAN PEMBAHASAN}

Berikut ini akan dijelasakan mengenai format file aplikasi dan contoh kasus yang dianalisis menggunakan aplikasi tersebut.

\subsection{Hasil Paket Program}

Hasil paket program aplikasi berupa file executable (*.exe) hasil compiling dari Program Lazarus yang berdiri sendiri dan dapat dijalankan seperti program biasa tanpa harus melakukan instalasi. Paket Aplikasi ini dinamakan Desain Blok Acak Lengkap.

\subsection{Contoh Analisis}

Misalkan terdapat data hasil eksperimen dalam Montgomery (2012) mengenai sebuah eksperimen yang dilakukan untuk mengetahui apakah terdapat efek dari penggunaan empat jenis ujung tester yang berbeda pada kekuatan baja. Mesin beroperasi dengan cara menekan ujung tester pada plat baja, dari kedalaman penekanan tersebut kekuatan plat dapat ditentukan. Dalam percobaan ini, peneliti menggunakan empat macam plat baja yang berbeda, sehingga desainnnya menggunakan DBAL. Hasil percobaan tampak seperti tabel berikut.

Tabel 3. Hasil Eksperimen Tingkat Kekerasan Baja

\begin{tabular}{|c|c|c|c|c|}
\hline \multirow{2}{*}{$\begin{array}{c}\text { Jenis } \\
\text { Plat }\end{array}$} & \multicolumn{4}{|c|}{ Jenis Ujung Tester } \\
\cline { 2 - 5 } & $\mathbf{1}$ & $\mathbf{2}$ & $\mathbf{3}$ & $\mathbf{4}$ \\
\hline 1 & 9,3 & 9,4 & 9,2 & 9,7 \\
\hline 2 & 9,4 & 9,3 & 9,4 & 9,6 \\
\hline 3 & 9,6 & 9,8 & 9,5 & 10,0 \\
\hline 4 & 10,0 & 9,9 & 9,7 & 10,2 \\
\hline
\end{tabular}

Data tersebut akan dianalisis menggunakan aplikasi praktis dan diperoleh hasil sebagai berikut: 


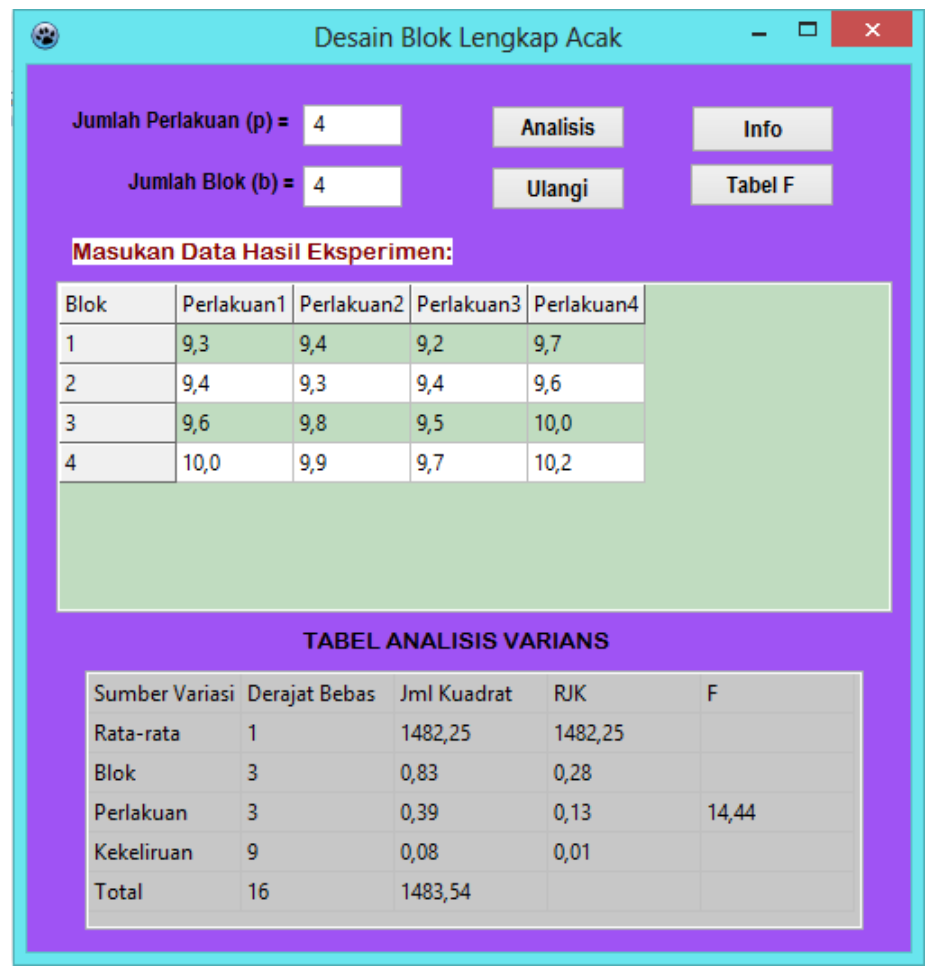

Gambar 5. Analisis menggunakan Aplikasi Praktis DBAL

Berdasarkan gambar terlihat bahwa F Hitung 14,44 yang apabila dibandingkan dengan Tabel $\mathrm{F}$ dengan taraf nyata $\alpha=5 \%$ dan derajat bebas $(3,9)=3,86$ yang dapat dilihat pada Tabel F pada menu. Dan apabila diklik menu tersebut akan menampilkan beberapa kemungkinan nilai F tabel seperti Gambar berikut:

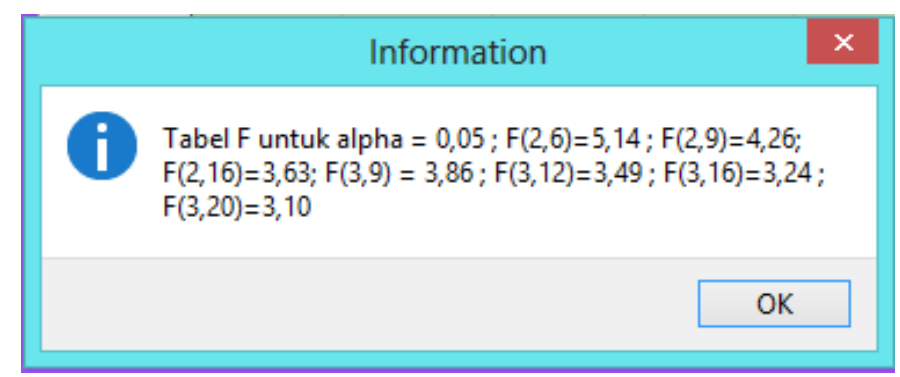

Gambar 6. Kotak Dialog untuk Informasi Tabel F

Sehingga pengujian signifikan karena $\mathrm{F}$ hitung $>\mathrm{F}$ tabel, kesimpulan dari pengujian adalah perbedaan jenis ujung tester memberikan efek terhadap tingkat kekerasan baja. 


\section{KESIMPULAN DAN SARAN}

Aplikasi Praktis DBAL sangat mudah untuk digunakan karena input data sesuai dengan format pengambilan data hasil eksperimen yang dapat langsung dicopy-kan kedalam isian data pada program dan ukuran filenya juga cukup kecil hanya 19 Megabyte saja. Aplikasi ini berupa executable file, sehingga tidak perlu instalasi dan bisa langsung dipergunakan.

Beberapa hal yang masih akan terus dikembangkan mengenai aplikasi ini adalah menentukan nilai p-value berdasarkan distribusi F. Bagi pengguna aplikasi ini diharapkan memperhatikan format data hasil pencatatan eksperimen terlebih dahulu, mana yang menjadi perlakuan dan mana yang menjadi blok, sehingga tidak terbalik pada saat melakukan entry data.

\section{UCAPAN TERIMA KASIH}

Penulis mengucapkan banyak terima kasih kepada tim dosen pemrograman komputer yang telah bersedia berdiskusi terkait dengan penyusunan program ini dan dapat terelialisasi menjadi suatu paket program yang easy-to-use.

\section{DAFTAR PUSTAKA}

Andini, R., Rancangan acak kelompok dengan MINITAB, http://riaandiniry.blogspot.co.id/2015/06/rancangan-acak-kelompokdengan-minitab.html, diakses pada 11 Juni 2015.

Lauterboom, D. P., Analisis Data Dengan Menggunakan MINITAB dan SAS, http://dansboom.blogspot.co.id/2010/08/analisis-data-denganmenggunakan.html, diakses pada Agustus 2010.

Mathews, P. G., Design of Experiments with MINITAB, Quality Press, Milwaukee, 2005.

Montgomery, D. C., Design and Analysis of Experiments, John Wiley \& Sons, Canada, 2012.

Pitri, N., Menganalisis Data Rancangan Acak Kelompok (RAK) Pola Faktorial Dengan Microsoft Excel Dan Program SPSS 16.0, 
http://nailulpitri.blogspot.co.id/2014/05/menganalisis-data-rancanganacak_7435.html, diakses pada 24 Mei 2014.

Rahmiyana, E., Cara Menganalisis Data Dengan Program SPSS untuk RAK Non

Faktorial, http://evirahmiyana.blogspot.co.id:

http://evirahmiyana.blogspot.co.id/2014/06/cara-menganalisis-datadengan-program_1.html, diakses pada 1 Juni 2014.

Sudjana, Desain dan Analisis Eksperimen, Edisi IV, Tarsito, Bandung, 2002.

Tantular, B., Pemrograman Komputer, Departemen Statistika FMIPA Unpad, Bandung, 2013.

Team, L. A., http://www.lazarus-ide.org/, diakses pada 1 Oktober 2016. 
